\title{
The effect of interleukin- $1 \beta$ and interleukin- 6 genetic polymorphisms on sickle cell disease course in childhood: an Egyptian study
}

\author{
Mervat Khorshied $^{1}$, Ola Ibrahim², Alaa Gad ${ }^{1}$, Mona El-Ghamrawy ${ }^{3}$
}

\begin{abstract}
${ }^{1}$ Department of Clinical Pathology, Faculty of Medicine, Cairo University, Cairo, Egypt 2Department of Child Health, National Research Institute, Cairo, Egypt ${ }^{3}$ Department of Pediatrics, Faculty of Medicine, Cairo University, Cairo, Egypt
\end{abstract}

Submitted: 23 April 2018

Accepted: 20 May 2018

Arch Med Sci Civil Dis 2018; 3: e57-e63

DOI: https://doi.org/10.5114/amscd.2018.76830

Copyright @ 2018 Termedia \& Banach

\section{Abstract}

Introduction: Sickle cell disease (SCD) is a chronic inflammatory disorder characterized by altered levels of several inflammatory cytokines, which may be regulated by genetic polymorphisms and could be associated with diverse clinical presentations. Interleukin $1 \beta$ (IL-1) and interleukin 6 (IL-6) have a pivotal role in the pathogenesis of many acute and chronic diseases, and their genetic alterations have been considered as molecular contributors to several inflammatory disorders. The current study aimed to define the impact of IL-1 $\beta$ and IL- 6 genetic polymorphisms on the clinical course of the disease in a cohort of pediatric SCD patients.

Material and methods: Genotyping of IL-1 $\beta+3954 \mathrm{C} / \mathrm{T}$ and IL- $6-174 \mathrm{G} / \mathrm{C}$ polymorphisms was performed by the polymerase chain reaction restriction fragment length polymorphism (PCR-RFLP) technique for 84 SCD patients and 100 age- and gender-matched unrelated healthy controls.

Results: The polymorphic genotypes of IL- $6-174 \mathrm{G} / \mathrm{C}$ were associated with patients suffering from repeated, severe attacks of vaso-occlusion (VOC) requiring hospitalization ( $p=0.023$ and $p=0.03$ respectively), while no significant differences were noted between SCD patients harboring the wild or the polymorphic genotypes of IL-1 $\beta+3954 \mathrm{C} / \mathrm{T}$ and their demographic, clinical or laboratory characteristics.

Conclusions: IL- $6-174 \mathrm{G} / \mathrm{C}$ polymorphism could be considered as a molecular predictor for recurrent, severe attacks of vascular occlusion in Egyptian SCD patients. Considering the important roles of cytokines in SCD pathophysiology, further investigations in larger cohorts are recommended for better characterization of individual variations in immune regulatory genes and identification of novel markers for disease complications and morbidity.

Key words: Egypt, sickle cell disease, IL-1 $\beta+3954$ C/T, IL-6 -174 G/C.

\author{
Corresponding author: \\ Alaa Gad \\ Department \\ of Clinical Pathology \\ Faculty of Medicine \\ Cairo University \\ 6A Aswan Square \\ Mohandseen \\ 12311 Cairo, Egypt \\ Phone: 02-01222260300 \\ E-mail:aag0121@ \\ my.londonmet.ac.uk
}

\section{Introduction}

Sickle cell anemia is one of the most common monogenic red cell disorders worldwide. It is a multi-system disorder, associated with episodes of acute illness, progressive organ damage and premature death $[1,2]$. Although all homozygous sickle cell disease patients have the same genetic alteration in their DNA, they experience a wide spectrum of clinical manifestations, ranging from an almost asymptomatic condition to severe illness. Moreover, the pathophysiology of sickle cell disease (SCD) complications remains incompletely understood, and this could be 
attributed to the interplay of environmental, psychosocial and genetic factors [3]. Sickle cell disease complications comprise hemolytic anemia, occlusions of the microcirculation and frequent infections resulting in painful vaso-occlusive crisis (VOC) leading to chronic organ injury [4]. Sickle cell disease is characterized by both acute and chronic inflammation [5], in which the chronic inflammatory state is associated with endothelial damage, increased production of reactive oxygen species, hemolysis or sickle red blood cells (RBCs), increased expression of adhesion molecules by leukocytes, erythrocytes, and platelets as well as increased production of pro-inflammatory cytokines via the adaptive immune response [6].

Interleukins are members of the inflammatory cytokine family that play a pivotal role in the inflammatory response and in the regulation of the immune system [7]. $1 \beta$ (IL-1 $\beta$ ) and interleukin 6 (IL-6) have been shown to be strongly incriminated, as both interleukin IL-1 $\beta$ and IL- 6 have a major role in the pathogenesis of many acute and chronic disorders, and their genetic polymorphisms could be considered as risk factors, disease modulators or prognostic markers in several inflammatory conditions.

Interleukin-6 (IL-6) is a multifunctional cytokine with pro-inflammatory and anti-inflammatory properties. It is one of the major mediators that drive the acute phase immune response [8]. Apart from stimulation of B-cell proliferation and differentiation into plasma cells, it induces production of acute phase proteins by hepatocytes, together with activation and differentiation of T-cells into cytotoxic cells and induction of hematopoiesis $[9,10]$. Replacement of guanine by cytosine at the promoter region of the IL- 6 gene at position -174 results in a functional promoter polymorphism of the IL- 6 gene, which affects the IL- 6 gene transcription rate and subsequently alters its plasma level. Elevated IL-6 levels may cause cellular damage due to oxidative stress, the release of other cytokine such as IL-1 $\beta$ and tumor necrosis factor $\alpha$ (TNF- $\alpha$ ), as well as the production of adhesion molecules and hepatic acute phase proteins $[9,11]$. In vivo studies investigating the role of the $-174 \mathrm{G} / \mathrm{C}$ promoter polymorphism on plasma IL-6 level revealed conflicting results; the study of Fishman et al. [12] reported that single nucleotide change from $G$ to $C$ at position -174 resulted in suppression of IL- 6 transcription and hence decreased production of IL-6. However, another study by Jones et al. [13] revealed that the plasma levels of IL- 6 were higher in those with the polymorphic (C) allele and CC genotype compared to those harboring the $\mathrm{G}$ allele and GG/GC genotypes [13].

Interleukin-1 is a pro-inflammatory cytokine involved in induction of apoptosis in response to cell injury. Bursts of IL-1 $\beta$ precipitate acute attacks of either systemic or local inflammation and contribute to several chronic diseases [14]. More than 20 single nucleotide polymorphisms (SNPs) have been reported in the IL-1 $\beta$ gene. The most important are -511 (rs16944), +3954 (rs1143634) and -31 loci. They exhibit a strong influence on gene transcription and eventual functional alterations; nonetheless, they have been associated with several immune and inflammatory disorders [11]. Previous studied reported that the variant (T) allele of IL-1 $\beta+3954$ is associated with high production of IL-1 $\beta[15,16]$. The T allele therefore could be considered as a molecular marker associated with shifting the cytokine profile toward a pro-inflammatory pattern. The impact of this variant allele has already been shown in various diseases such as ulcerative colitis, insulin-dependent diabetes mellitus, myasthenia, periodontitis and rheumatoid arthritis [17-23].

The magnitude of cytokine production depends not only on antigenic challenge but also on host genetic factors. The study of SNPs has now become a potential tool not only for better understanding of the etiopathogenesis of the disease, but also as a probable marker of disease susceptibility and severity. The aim of the current study was to study the possible role of IL- $1 \beta+3954$ $\mathrm{C} / \mathrm{T}$ and IL- $6-174 \mathrm{G} / \mathrm{C}$ genetic polymorphisms as molecular modulators of the course of sickle cell disease in a cohort of pediatric Egyptian SCD patients.

\section{Material and methods}

\section{Study population}

The present study included 84 pediatric Egyptian SCD patients from the Pediatric Hematology Clinic of El-Mounira Children's Hospital, Cairo University. They were 54 males and 30 females. Their ages ranged between 5 and 18 years. Diagnosis of SCD was based on proper history taking including family history of similar conditions or other hemoglobinopathies along with thorough clinical examination for signs associated with SCD. Laboratory investigations including complete blood picture and peripheral blood examinations for detection of sickled RBCs, the sickling test, hemoglobin electrophoresis and high performance liquid chromatography (HPLC) were all done to confirm SCD. The clinical and laboratory evaluations were done at presentation as well as follow-up visits. Assessment of the severity of veno-occlusive crises (VOC) was done with a working definition of VOC which stratifies the patients according to their clinical conditions. In moderate to severe cases, the patients suffered from pain in the extremities, back, abdomen, chest, or head that led 
them to unscheduled clinic or emergency room visits and that required narcotics as well as hospitalization which could not be explained except by SCD, with exclusion of hand-foot syndrome, chest syndrome, osteomyelitis, and any episode of pain that was treated entirely at home. One hundred age- and sex-matched healthy children with normal hemoglobin electrophoresis were included in the study as a control group. Informed consent was obtained from the parents or guardians of participants in advance and the study was approved by the Research Ethics Committee of the Faculty of Medicine, Cairo University. All procedures performed were in accordance with the 1964 Helsinki Declaration.

Genotyping of IL-1 $\beta+3954$ C/T (rs1143634) and IL-6 -174 G/C (rs1800795) SNPS

Genomic DNA was extracted from peripheral blood leucocytes by the QIAamp genomic DNA purification kit (Fermentas Life Sciences, Canada) according to the manufacturer's instructions. Samples were stored in elution buffer at $-20^{\circ} \mathrm{C}$ until being used. Genotyping of IL-1 $\beta+3954 \mathrm{C} / \mathrm{T}$ (rs1143634) and IL-6 -174 G/C (rs1800795) SNPs was done by polymerase chain reaction restriction fragment length polymorphism (PCR-RFLP) assay $[14,20]$.

For detection of IL-1 $\beta+3954$ C/T polymorphism, genomic DNA was amplified using the following set of primers: 5'-TCAGGTGTCCTCGAAGAAATCAAA-3' and $5^{\prime}$-GGTTTTTTGCTGTGAGTCCC-3'. The thermocycler program conducted was initial heating at $95^{\circ} \mathrm{C}$ for $5 \mathrm{~min}$, followed by 30 cycles of denaturation at $95^{\circ} \mathrm{C}$ for $30 \mathrm{~s}$, annealing at $54^{\circ} \mathrm{C}$ for 30 $\mathrm{s}$ and extension at $72^{\circ} \mathrm{C}$ for $30 \mathrm{~s}$ with a final extension step for $5 \mathrm{~min}$ at $72^{\circ} \mathrm{C}$. The PCR product was visualized on $2 \%$ ethidium bromide stained agarose gel under UV light. The PCR product was incubated with Taql restriction endonuclease (Fermentas, Lithuania) at $65^{\circ} \mathrm{C}$ overnight. The common (wild type; C) allele was restricted into two fragments of 108 and $86 \mathrm{bp}$, while the polymorphic $(\mathrm{T})$ allele was not restricted, remaining as a single band of $194 \mathrm{bp}$.

For genotyping of IL-6 -174 G/C SNP, the primer set used for amplifying the target gene was 5'-TGACTTCAGCTTTACTCTTGT-3' and 5'-CTGATTGGAAACCTTATTAAG-3'. The thermocycler program applied was initial denaturation at $95^{\circ} \mathrm{C}$ for $10 \mathrm{~min}$, followed by 35 cycles of $95^{\circ} \mathrm{C}$ for $45 \mathrm{~s}$, $52^{\circ} \mathrm{C}$ for $45 \mathrm{~s}$, and $72^{\circ} \mathrm{C}$ for $1 \mathrm{~min}$, followed by a final extension step at $72^{\circ} \mathrm{C}$ for $10 \mathrm{~min}$. The PCR product was visualized on $2 \%$ ethidium bromide stained agarose gel under UV light as a 164 bp band. The amplicon was incubated with Nlalll endonuclease at $37^{\circ} \mathrm{C}$ for $4 \mathrm{~h}$, and then restriction fragments were analyzed. The wild type allele ( $G$ allele) was restricted into two fragments of 111 and $53 \mathrm{bp}$, while the variant allele (C allele) did not show a single band of $164 \mathrm{bp}$. For quality control, genotyping was repeated with respect to case/ control status for 50 samples. Genotyping was determined blindly by two different observers, and was $100 \%$ concordant.

\section{Statistical analysis}

Data were analyzed using SPSS (Statistical Package for the Social Sciences; SPSS Inc., Chicago, IL, USA) statistical package version 21. For numerical data, parametric data were expressed as mean, standard deviation, and range, while nonparametric data were expressed as median and interquartile range. Qualitative data were expressed as frequency and percentage. The $\chi^{2}$ test or Fisher's exact test was used to examine the relation between qualitative variables. Nonparametric numerical data were analyzed using the Mann-Whitney test. Correlation analysis was performed by Spearman's rank correlation. Unconditional logistic regression analysis was used to calculate odds ratios (OR) and 95\% confidence intervals $(\mathrm{Cl})$ for risk estimation. Homozygotes of the most frequent genotype were regarded as the reference group. $P$-values less than 0.05 were considered significant. The $\chi^{2}$ test was performed to assess deviation from Hardy-Weinberg equilibrium (HWE). Genotypic distribution of the studied SNPs was in accordance with the Hardy-Weinberg equilibrium $(p>0.05)$.

\section{Results}

The current study was conducted on 84 pediatric SCD patients aged $5-18$ years (54 males and 30 females). One hundred unrelated healthy children of the same age group (65 males and 35 females) were included in the study as a control group. Demographic, clinical and hematological characteristics of SCD patients are presented in Table I. Diagnosis of SCD was based on clinical and laboratory assessment. According to hemoglobin electrophoresis results and HPLC pattern, $60 / 84(71.5 \%)$ cases were sickle cell anemia (Hb SS), while $24 / 84$ (28.5\%) were sickle $\beta$-thalassemia ( $\mathrm{Hb} \mathrm{S} \beta$ ). Sixty-nine patients gave a history of VOC. Assessment of the severity of VOC revealed that $37 / 69$ (56.5\%) of patients had moderate/severe attacks of vascular occlusion, while $32 / 69$ (43.5\%) had mild attacks.

The genotypic and allelic distributions of IL-1 $\beta$ +3954 C/T and IL-6-174G/C SNP in SCD patients and controls are presented in Table II. The studied SNPs were in Hardy-Weinberg equilibrium in the control group. The frequencies of the polymorphic genotypes of both SNPs were higher in SCD pa- 
Table I. Clinical and laboratory data of SCD patients $(n=84)$

\begin{tabular}{|c|c|c|c|}
\hline Item & Value & Item & Value \\
\hline \multicolumn{2}{|l|}{ Clinical data: } & \multirow{4}{*}{$\begin{array}{l}\text { Infrequent (1-3 times blood } \\
\text { transfusion/year) } \\
\begin{array}{l}\text { Sporadic (infection, preoperative, } \\
\text { occasional) }\end{array}\end{array}$} & 19 (22.6\%) \\
\hline \multirow{2}{*}{ Gender: male/female } & \multirow{3}{*}{$54 / 30$} & & \\
\hline & & & 18 (21.4\%) \\
\hline Age [years]: & & & \\
\hline Range & $5-18$ & \multirow{2}{*}{$\begin{array}{l}\text { Laboratory data: } \\
\text { Types: }\end{array}$} & \\
\hline Mean $\pm S D$ & $11.08 \pm 5.9$ & & \\
\hline \multicolumn{2}{|l|}{ Splenic status: } & $\mathrm{Hb}-\mathrm{SS}$ & $60(71.5 \%)$ \\
\hline Splenomegaly & 18 (21.4\%) & $\mathrm{S} / \beta$-thalassemia $\left(\mathrm{Hb}-\mathrm{S} \beta^{+}\right)$ & $24(28.5 \%)$ \\
\hline Splenectomy & 23 (27.3\%) & \multicolumn{2}{|l|}{ Hemoglobin level [gm/dl]: } \\
\hline Hepatomegaly & $16(19 \%)$ & Range & $5.3-9.6$ \\
\hline Gallstones & $5(5.9 \%)$ & Mean \pm SD & $7.8 \pm 1.12$ \\
\hline Osteonecrosis & $5(5.9 \%)$ & \multicolumn{2}{|l|}{ Reticulocyte count (\%): } \\
\hline Leg ulcers & $3(3.5 \%)$ & Range & $1.5-30 \%$ \\
\hline Priapism & $5(5.9 \%)$ & Mean \pm SD & $11.7 \pm 6.9$ \\
\hline CNS complications (TIAs \& strokes) & $5(5.9 \%)$ & \multicolumn{2}{|l|}{ Total leucocytic count $\left[\times 10^{3} / \mathrm{cm}^{3}\right]$ : } \\
\hline Hand foot syndrome & $22(26.1 \%)$ & Range & $4.1-17.9$ \\
\hline VOC & $69(82.1 \%)$ & Mean \pm SD & $9.9 \pm 2.8$ \\
\hline \multirow{2}{*}{\multicolumn{2}{|c|}{$\begin{array}{l}\text { Moderate to severe VOC/year (requiring emergency } \\
\text { visit or hospitalization): }\end{array}$}} & \multicolumn{2}{|l|}{ Platelet count $\left[\times 10^{3} / \mathrm{cm}^{3}\right]$} \\
\hline & & Range & $88-764$ \\
\hline Range & $0-17$ & Mean \pm SD & $386 \pm 148$ \\
\hline Median & 4 & $\mathrm{HbS}(\%)($ mean $\pm \mathrm{SD}):$ & \\
\hline Mean \pm SD & $4.1 \pm 4.7$ & $\mathrm{Hb}-\mathrm{SS}$ patients & $87.16 \pm 5.01$ \\
\hline Elevated pulmonary artery pressure & $10(11.9 \%)$ & \multirow{2}{*}{$\mathrm{Hb}-\mathrm{S} \beta$ patients } & 69.58 \\
\hline \multirow{2}{*}{$\begin{array}{l}\text { Frequency of blood transfusion } \\
\text { (units of blood/year): }\end{array}$} & & & \pm 10.11 \\
\hline & & $\mathrm{Hb} F(\%)($ mean \pm SD): & \\
\hline Range & $0-20$ & $\mathrm{Hb}-\mathrm{SS}$ patients & $8.91 \pm 7.6$ \\
\hline Median & 4 & $\mathrm{Hb}-\mathrm{S} \beta$ patients & $12.9 \pm 8.67$ \\
\hline Mean \pm SD & $5.6 \pm 4.7$ & $\mathrm{Hb}$ A2 (\%) (mean \pm SD): & \\
\hline Transfusion dependency: & & $\mathrm{Hb}$-SS patients & $4.13 \pm 3.1$ \\
\hline $\begin{array}{l}\text { Frequent ( }>4 \text { times blood } \\
\text { transfusion/year) }\end{array}$ & $47(55.9 \%)$ & $\mathrm{Hb}-\mathrm{S} \beta$ patients & $4.07 \pm 5.46$ \\
\hline
\end{tabular}

TIAs - transient ischemic attacks, VOC - vaso-occlusive crisis.

tients than controls, but the differences were not statistically significant. Multivariate regression analysis was performed to verify the possible association between the studied genetic polymorphisms and other factors that could affect the disease course - $\mathrm{Hb}$ level, $\mathrm{HbF}$ percentage and treatment with hydroxyurea. Statistical comparison between patients having the wild genotype (CC) and the polymorphic genotypes of IL-1 $\beta$ (CT and TT) did not show significant differences between the 2 patient groups regarding their gender, presenting symptoms, frequency and se- verity of VOC, frequency of blood transfusion, organomegaly, hand-foot syndrome, disease-related complications including leg ulcers, priapism, elevated pulmonary artery pressure, osteonecrosis, CNS complications or other laboratory features. As for IL-6-174 G/C SNP, the polymorphic variants (GC and CC) were significantly more frequent among patients with repeated attacks of vascular occlusion (VOC) $(p=0.023)$, especially those with severe attacks requiring hospitalization or emergency visits $(p=0.03)$. Otherwise, no significant difference was found between SCD patients har- 
Table II. Genotypic and allelic distribution of IL-1 $\beta+3954$ C/T and IL-6 -174 G/C in SCD patients and controls

\begin{tabular}{|c|c|c|c|c|}
\hline Genotype & Controls $(N=100)$ & SCD patients $(N=84)$ & OR $(95 \% \mathrm{Cl})$ & $P$-value \\
\hline \multicolumn{5}{|l|}{ IL-1 $\beta+3954 \mathrm{C} / \mathrm{T}:$} \\
\hline Wild genotype CC & $56 / 100(56 \%)$ & $39 / 84(46.4 \%)$ & 1 (Reference) & \\
\hline Heteromutant CT & $34 / 100$ (34\%) & $32 / 84(38.1 \%)$ & $1.19(0.65-2.19)$ & 0.104 \\
\hline Homomutant TT & $10 / 100(10 \%)$ & $13 / 84(15.5 \%)$ & $1.64(0.68-3.98)$ & 0.95 \\
\hline $\mathrm{CT}$ and $\mathrm{TT}$ & $44 / 100$ (44\%) & $45 / 84(53.6 \%)$ & $1.47(0.82-2.63)$ & 0.051 \\
\hline C allele & 0.73 & 0.65 & $1.45(0.8-2.66)$ & 0.058 \\
\hline T allele & 0.27 & 0.35 & & \\
\hline \multicolumn{5}{|l|}{ IL-6 -174 G/C: } \\
\hline Wild genotype GG & $31 / 100(31 \%)$ & $25 / 84(29.8 \%)$ & 1 (Reference) & \\
\hline Heteromutant GC & $59 / 100(59 \%)$ & $49 / 84(58.2 \%)$ & $0.97(0.54-1.75)$ & 0.12 \\
\hline Homomutant CC & $10 / 100(10 \%)$ & 10/84 (12\%) & $1.21(0.48-3.079)$ & 0.17 \\
\hline $\mathrm{GC}$ and $\mathrm{CC}$ & $69 / 100(69 \%)$ & $59 / 84(70.2 \%)$ & $1.06(0.56-1.2)$ & 0.26 \\
\hline G allele & 0.61 & 0.59 & $1.09(0.62-1.91)$ & 0.11 \\
\hline C allele & 0.39 & 0.41 & & \\
\hline \multicolumn{5}{|c|}{$\begin{array}{l}\text { Combined genotype analysis } \\
\text { IL-1 } \beta / \text { IL-6: }\end{array}$} \\
\hline $\mathrm{CC} / \mathrm{GG}$ & $15 / 100(15 \%)$ & $8 / 84(9.5 \%)$ & 1 (Reference) & \\
\hline $\mathrm{CC} / \mathrm{GC}+\mathrm{CC}$ & $41 / 100(41 \%)$ & $31 / 84(37.3 \%)$ & $0.92(0.24-1.48)$ & 0.45 \\
\hline$\overline{\mathrm{CT}+\mathrm{TT} / \mathrm{GG}}$ & $16 / 100(16 \%)$ & $17 / 84(20.2 \%)$ & $1.56(0.72-3.39)$ & 0.177 \\
\hline $\mathrm{CT}+\mathrm{TT} / \mathrm{GC}+\mathrm{CC}$ & $28 / 100(28 \%)$ & $28 / 84(33.3 \%)$ & $1.2990 .69-2.41)$ & 0.267 \\
\hline
\end{tabular}

$O R$ - odds ratio, $\mathrm{Cl}$ - confidence interval.

boring the wild or polymorphic genotypes and their gender, clinical characteristics, laboratory features or disease-related complications (data not shown).

\section{Discussion}

Sickle cell disease patients can experience a wide spectrum of disease-related complications with varying degrees of severity. Vasculopathy and vascular occlusion represent a major pathophysiologic event in SCD that could lead to a variety of morbidities such as painful crisis, acute chest syndrome, leg ulcers, stroke, priapism, aseptic necrosis of bones and proliferative retinopathy [24]. Previous studies have focused on identifying factors associated with these complications in an attempt to show their possible role as disease contributors and/or modifiers. However, such known causes are still insufficient to fully explain the clinical heterogeneity of the disease $[25,26]$.

Several lines of evidence implicated a state of chronic inflammation with VOC pathogenesis, evidenced by the elevated levels of the pro-inflammatory cytokines TNF- $\alpha$, IL- 6 and IL-17 and acute phase proteins in the sera of SCD patients during
VOC episodes [27, 28]. Previous studies reported an altered balance of inflammatory and anti-inflammatory cytokines in SCD patients during VOC, highlighted by elevation in pro-inflammatory cytokines and reduction in anti-inflammatory cytokine levels [28, 29].

The aim of the current study was to define the impact of IL- $1 \beta$ and IL- 6 genetic polymorphisms on the clinical course of the disease in a cohort of pediatric SCD patients. IL- $6-174 \mathrm{G} / \mathrm{C}$ genotypic frequencies in SCD patients were $58.2 \%$ and $12 \%$ for the heteromutant (GC) and the homomutant (CC) genotypes respectively. These frequencies differed greatly from those reported in Brazilian SCD patients, where the heteromutant genotype frequency ranged between $24 \%$ and $29 \%$, while the homomutant frequency ranged between $0 \%$ and $5 \%[25,30]$. This could possibly be explained by the ethnic difference between the studied cohorts and/or the difference in sample size. In our study, the genotypic frequencies in SCD patients were similar to those of the healthy controls. This was concomitant with the studies of Vicari et al. [5] and Olenscki Gilli et al. [25] in a Brazilian population. 
The interplay of sickle red cells, adherent leucocytes, activated endothelium, together with altered cytokine levels perpetuates a continuous inflammatory condition that predisposes SCD patients to VOC [31]. Thus the severity of VOC is attributed to the imbalance between pro- and anti-inflammatory mechanisms $[4,5]$. Statistical analysis revealed that the polymorphic genotypes of IL-6 $-174 \mathrm{G} / \mathrm{C}$ were significantly associated with repeated and moderate/severe attacks of VOC requiring emergency visits or hospitalization. This may be in part due to the inflammatory milieu induced by the high IL- 6 level in SCD patients harboring the variant allele of IL-6-174 G/C. The study of Vicari et al. [5] in Brazilian patients did not reveal differences between SCD patients having the wild or the polymorphic genotypes except for leg ulcers, which were more frequent in patients having the heteromutant genotype, GC.

Several association studies have suggested a genetic influence of the IL1 region in a diverse group of diseases that have an inflammatory component $[26,30]$. In SCD, IL-1 $\beta-511$ and +3954 SNP have been postulated to participate in vaso-occlusion through their role in the processes of inflammation, cellular adhesion, signaling, transport or coagulation [32, 33]. In the current study, genotypic analysis showed that $38.1 \%$ of SCD patients have the heteromutant genotype (CT) and $15.5 \%$ have the homomutant genotype (TT) of IL-1 $\beta+3954 \mathrm{C} / \mathrm{T}$ SNP. These frequencies were similar to those reported in Brazilian SCD patients, being $38 \%$ and $8 \%$ for the CT and TT genotypes [5]. Although the frequency of the polymorphic genotypes was higher in SCD patients than controls, the difference was not statistically significant. This is in line with a report previously published in Brazil [5].

Furthermore, there were no significant differences between patients having the wild genotype (CC) or the polymorphic genotypes (CT and TT) regarding their gender, presenting symptoms, clinical or laboratory features. In contrast, the study of Vicari et al. [5] in Brazilian sickle cell anemia patients reported that IL- $1 \beta+3954 \mathrm{C} / \mathrm{T}$ polymorphism is associated with osteonecrosis, elevated pulmonary arterial pressure and lower reticulocyte count. The discrepancy between the studies could be attributed to the type of sickle patients, as the Brazilian cohort had only sickle cell anemia (Hb SS), while our study included patients with sickle ( $\mathrm{Hb} \mathrm{SS}$ ) and sickle $\beta$-thalassemia $(\mathrm{Hb} \mathrm{S} \beta)$, who had a significant amount $\mathrm{HbF}$ that would reduce red cell sickling and subsequently disease-related complications and could ameliorate the disease course.

In Egyptian controls, 59\% had the heteromutant genotype, while $10 \%$ had the homomutant genotype of IL-6 $-174 \mathrm{G} / \mathrm{C}$. These genotypic frequencies were similar to those reported in UK Caucasians
[34] and Germans [12]. On the other hand, these frequencies differed greatly from those reported in Brazilian, Chinese, Indian, Afro-Caribbean and Polish populations [12, 24]. These observations could be attributed to the ethnic difference between the studied populations. As for IL-1 $\beta+3954 \mathrm{G} / \mathrm{C}, 34 \%$ had the heteromutant genotype (CT), and $10 \%$ had the homomutant genotype (TT). These frequencies are in line with those reported in Brazil [5], Poland [34], the USA [17] and the Netherlands [33].

In conclusion, the current study demonstrated the genotypic distribution of IL- $1 \beta+3954 \mathrm{G} / \mathrm{C}$ and IL-6 -174G/C SNPs in a cohort of Egyptian SCD patients, and compared it with previous cohorts. The polymorphic genotype of IL- $6-174 \mathrm{G} / \mathrm{C}$ SNP was higher in SCD patients compared to the controls. This genotypic signature seems to render a more "inflammatory" phenotype for the evaluated SCD patients. Additionally, IL-6-174 G/C polymorphism could be considered as a molecular predictor for repeated severe attacks of vascular occlusion in Egyptian SCD patients.

As genetic alterations of immune regulatory genes could play a pivotal role in SCD pathogenesis as well as disease course, investigations with larger cohorts are recommended for better characterization of patients prone to complications and for identification of novel molecular markers that could influence the disease course and subsequently disease morbidity and mortality. Further understanding of these mechanisms may provide novel therapeutic targets and strategies for sickle cell disease.

\section{Acknowledgments}

We would like to express our gratitude to the Faculty of Medicine, Cairo University for giving us the chance to accomplish this piece of work with the help of its competent technicians and the updated equipment and instrumentation.

This research did not receive any specific grant from funding agencies in the public, commercial, or not-for-profit sectors.

\section{Conflict of interest}

The authors declare no conflict of interest.

\section{References}

1. Weatherall D, Hofman K, Rodgers G, Ruffin J, Hrynkow $S$. A case for developing north-south partnerships for research in sickle cell disease. Blood 2015; 105: 921-3.

2. Abraham A, Jacobsohn D, Bollard C. Cellular therapy for sickle cell disease. Cytotherapy 2016; 18: 1360-9.

3. Fertrin K, Costa F. Genomic polymorphisms in sickle cell disease: implications for clinical diversity and treatment. Expert Rev Hematol 2010; 3: 443-58.

4. Sarray S, Saleh LR, Saldanha FL, Al-Habboubi HH, Mahdi N, Almawi WY. Serum IL-6, IL-10, and TNFa levels in 
pediatric sickle cell disease patients during vasoocclusive crisis and steady state condition. Cytokine 2015 72: 43-7.

5. Vicari P, Adegoke SA, Mazzotti DR, Cançado RD, Nogutti MA, Figueiredo MS. Interleukin-1beta and interleukin-6gene polymorphisms are associated with manifes tations of sickle cellanemia. Blood Cells Mol Dis 2015 54: $244-9$

6. Bandeira IC, Rocha LB, Barbosa MC, et al. Chronic inflammatory state in sickle cell anemia patients is as sociated with $\mathrm{HBB}\left(^{*}\right) \mathrm{S}$ haplotype. Cytokine 2014; 65: 217-21.

7. Chi DZ, Chen J, Huang DP. Influence of interleukin-1beta and interleukin- 6 gene polymorphisms on the development of acute pancreatitis. Genet Mol Res 2015; 14 975-80

8. Heinrich PC, Castell JV, Andus T. Interleukin-6 and the acute phase response. Biochem J 1990; 265: 621-36.

9. Olomolaiye $\mathrm{O}$, Wood N, Bidwell J. A novel Nlalll polymorphism in the human IL-6 promoter. Eur J Immunogenet 1998; 25: 267.

10. Yang $W, Y u X$, Wang $C$, et al. Interleukin-1beta in intervertebral disk degeneration. Clin Chim Acta 2015; 450: 262-72

11. Chen H, Wilkins L, Aziz N, et al. Single nucleotide polymorphisms in the human interleukin-1B gene affects transcription according to haplotype context. Hum Mo Genet 2006; 15: 519-29.

12. Fishman D, Faulds G, Jeffery R, et al. The effect of novel polymorphisms in the interleukin-6 (IL-6) gene on IL-6 transcription and plasma IL- 6 levels, and an association with systemic-onset juvenile chronic arthritis. J Clin Invest 1998; 102: 1369-76.

13. Jones KG, Brull DJ, Brown LC, et al. Interleukin-6 (IL-6) and the prognosis of abdominal aortic aneurysms. Circulation 2001; 103: 2260-5.

14. Allam I, Djidjik R, Ouikhlef N, et al. Interleukin-1 and the interleukin-1 receptor antagonist gene polymorphisms study in patients with rheumatoid arthritis. Pathol Biol 2013; 61: 264-8.

15. Di Giovine FS, Cork MJ, Crane A, Mee JB, Duff GW. Novel genetic association of an IL-1B gene variation at +3953 with IL-1beta protein production and psoriasis. Cytokine 1995; 7: 606 (Abstr. A665).

16. Pociot F, Molvig J, Wogensen L, Worsaae H, Nerup J. A Taql polymorphism in the human interleukin-1 beta (IL-1 beta) gene correlates with IL-1beta secretion in vitro. Eur J Clin Invest 1992; 22: 396-402.

17. Buchs N, di Giovine FS, Silvestri T, et al. IL-1B and IL-1Ra gene polymorphisms and disease severity in rheumatoid arthritis: interaction with their plasma levels. Genes Immunol 2001; 2: 222-8.

18. Gaudino M, Castelnuovo A, Zamparelli R, et al. Genetic control of postoperative systemic inflammatory reaction and pulmonary and renal complications after coronary artery surgery. J Thorac Cardiovasc Surg 2003; 126 1107-12.

19. Mazur G, Bogunia-Kubik K, Wrobel T, et al. IL-6 and IL-10 promoter gene polymorphisms do not associate with the susceptibility for multiple myeloma. Immunol Lett 2005; 96: 241-6.

20. Gao S, Liang S, Pan M, et al. Interleukin- 6 genotypes and serum levels in Chinese Hui population. Int J Clin Exp Med 2014; 7: 2851-7.

21. Kato G, Gladwin M, Steinberg M. Deconstructing sickle cell disease: reappraisal of the role of hemolysis in the development of clinical sub-phenotypes. Blood Rev 2007; 21: 37-47.
22. Steinberg M, Rodgers G. Pathophysiology of sickle cell disease: role of cellular and genetic modifiers. Semin Hematol 2001; 38: 299-306.

23. Pathare A, Kindi S, Daar S, et al. Cytokines in sickle cell disease. Hematology 2003; 8: 329-37.

24. Vicari P, Silva G, Nogutti $M$, et al. Absence of association between TNF-alpha polymorphism and cerebral large-vessel abnormalities in adults with sickle cell anemia. Acta Haematol 2011; 125: 141-4.

25. Olenscki Gilli S, Pericole F, Benites B, et al. Cytokine polymorphisms in sickle cell disease and the relationship with cytokine expression. Exp Hematol 2016; 44: 583-9.

26. Duff GW. Genetic variation in cytokines and relevance to inflammation and disease. In: The Cytokine Network. Frontiers in Molecular Biology. Balkwill F (ed.). Oxford University Press, Oxford 2000; 25: 152.

27. Lanaro C, Franco-Penteado CF, Albuqueque DM, Saad ST, Conran N, Costa FF. Altered levels of cytokines and inflammatory mediators in plasma and leukocytes of sickle cell anemia patients and effects of hydroxyurea therapy. J Leukoc Biol 2009; 85: 235-42.

28. Musa BO, Onyemelukwe GC, Hambolu JO, Mamman AI, Isa $\mathrm{AH}$. Pattern of serum cytokine expression and T-cell subsets in sickle cell disease patients in vaso-occlusive crisis. Clin Vaccine Immunol 2010; 17: 602-8.

29. Keikhaei B, Mohseni AR, Norouzirad R, et al. Altered levels of pro-inflammatory cytokines in sickle cell disease patients during vaso-occlusive crises and the steady state condition. Eur Cytokine Netw 2013; 24: 45-52.

30. Dinarello CA. A clinical perspective of IL-1beta as the gatekeeper of inflammation. Eur J Immunol 2011; 41: 1203-17.

31. Manwani D, Frenette PS. Vaso-occlusion in sickle cell disease: pathophysiology and novel targeted therapies. Blood 2013; 122: 3892-98.

32. Elliott L, Ashley-Koch A, De Castro L, et al. Genetic polymorphisms associated with priapism in sickle cell disease. Br J Haematol 2007; 137: 262-7.

33. Nemetz A, Nosti-Escanilla MP, Molnár T, et al. IL1B gene polymorphisms influence the course and severity of inflammatory bowel disease. Immunogenetics 1999; 49 : 527-31.

34. Wujcicka W, Gaj Z, Wilczyński J, Nowakowska D. Contribution of IL6 -174 G>C and IL1B +3954 C>T polymorphisms to congenital infection with Toxoplasma gondii. Eur J Clin Microbiol Infect Dis 2015; 34: 2287-94. 